\title{
Management tools applied to milk quality in cattle farming in the Western Amazon
}

\section{Ferramentas de gestão aplicadas à qualidade do leite na bovinocultura na Amazônia Ocidental}

\author{
Luane Pereira Linhares ${ }^{1 *}$; Eduardo Mitke Brandão Reis²; Marcos Aurelio Lopes ${ }^{3 ;}$ \\ Gerbson Francisco Nogueira Maia4; Camilla Birenbaum Nobile5; Patrícia Gelli \\ Feres de Marchi ${ }^{6}$; Paulo Márcio Beber ${ }^{7}$; Antonia Valcemira Domingos de Oliveira ${ }^{8}$
}

\section{Highlights}

Propriedades leiteiras em regime familiar, não aplicam boas práticas de ordenha.

Ferramentas de gestão podem gerar resultados significativos na qualidade do leite.

Implantação das práticas de ordenha obteve redução média de 31,4\% CCS e 63\% CBT.

Ferramentas de gestão auxiliam na identificação de pontos fracos no sistema de ordenha.

\begin{abstract}
This study aimed to analyze the applicability of management tools such as SWOT matrix, GUT matrix, Brainstorming, PDCA, Ishikawa diagram, and $5 \mathrm{~W} 2 \mathrm{H}$ in improving milk quality in rural properties for family labor. The survey was conducted in 18 properties in the municipality of Senador Guiomard, State of Acre, Brazil, during the period from January to December 2019. The properties were divided into two groups (treatment group-TG and control group-CG) and the data obtained through a form with 255 questions for diagnosis and analysis (LQL-GO) for somatic cell count (SCC) and total bacterial count (TBC) were tabulated
\end{abstract}

1 Veterinary Doctor, Master of the Postgraduate Program in Sustainable Animal Health and Production in the Western Amazon, Universidade Federal do Acre, UFAC, Rio Branco, AC, Brazil. E-mail: luanelinharesmv@gmail.com

2 Veterinary Doctor, Dr. in Veterinary Science. Professor at the Postgraduate Program in Animal Health and Production, UFAC, Rio Branco, AC, Brazil. E-mail: edumitke@gmail.com

3 Prof. Dr. in Animal Science, Department of Veterinary Medicine at the Universidade Federal de Lavras, UFLA, MG, Brazil. E-mail: malopes@dmv.ufla.br

${ }^{4}$ Agronomic Engineer, PhD Student in the Postgraduate Program in Animal Health and Production in the Western Amazon at the UFAC, Rio Branco, AC, Brazil. E-mail: maia.ger123@hotmail.com

5 Veterinary Doctor, Master of the Postgraduate Program in Sustainable Animal Health and Production in the Western Amazon UFAC, Rio Branco, AC, Brazil. E-mail: camillabnobile@gmail.com

${ }^{6}$ Veterinary Doctor, Doctor in Veterinary Sciences, Adjunct Professor at the Center for Biological and Nature Sciences at the UFAC, Rio Branco, AC, Brazil. E-mail: patriciamarchi.ufac@gmail.com

7 Agronomic Engineer, Doctor in Agronomy/Plant Production. Professor Federal Institute of Acre, EBTT, Agriculture of the Federal Institute of Acre, Sena Madureira, AC, Brazil. E-mail: paulo.beber@ifac.edu.br

8 Zootechnician, Master's Student of the Post-Graduate Program in Sanitation and Sustainable Animal Production in the Western Amazon, at the UFAC, Rio Branco, AC, Brazil. E-mail: valcemira@hotmail.com

* Author for correspondence

Received: Mar. 18, 2021 - Approved: June 02, 2021 
in spreadsheets $\left(\mathrm{Exce}^{\circledR}\right)$ and subjected to statistical analysis by the Wilcoxon test. Nineteen weaknesses were obtained through the GUT matrix. The implementation of milking practices using tools obtained an average reduction of $31.4 \%$ for SCC and $63 \%$ for TBC in TG and a reduction of $39.3 \%$ for SCC and an increase of $33.7 \%$ for TBC in CG. Thus, the management tools applied to milk quality are capable of generating positive results $(p<0.05)$ in microbiological control, facilitating quick decision-making, aiming at the correction of weaknesses, and, consequently, an increase in profitability.

Key words: Good milking practices. Management. Quality indicators. Planning.

\section{Resumo}

Objetivou-se analisar a aplicabilidade de algumas ferramentas de gestão como: matriz SWOT, matriz GUT, Brainstorming, PDCA, diagrama de Ishikawa e 5W2H na melhoria da qualidade do leite em 18 propriedades rurais em regime de economia familiar, localizadas no município de Senador Guiomard, Acre, durante o período de janeiro a dezembro de 2019. As propriedades foram divididas em dois grupos (grupo tratamento-GT e controle-GC), e os dados foram obtidos utilizando-se um formulário com 255 questões para o diagnóstico, e por meio de análises (LQL-GO) para contagem de células somáticas (CCS) e contagem bacteriana total (CBT); posteriormente tabulados em planilhas (Excel $\left.{ }^{\circledR}\right)$ e submetidos à análise estatística pelo teste de Wilcoxon. Obteve-se, por meio da Matriz GUT, 19 pontos fracos. A implantação das práticas de ordenha por meio das ferramentas obteve redução média de 31,4\% para CCS e 63\% para CBT no GT, enquanto o GC obteve redução de 39,3\% para CCS e aumento de 33,7\% para CBT. Conclui-se que as ferramentas de gestão aplicadas à qualidade do leite são capazes de gerar resultados positivos $(p<0,05)$ no controle microbiológico, facilitando a tomada rápida de decisões visando à correção de pontos falhos e, consequentemente, o aumento da rentabilidade.

Palavras-chave: Boas práticas de ordenha. Gestão. Indicadores de qualidades. Planejamento.

\section{Introduction}

The milk production chain has great importance to the Brazilian agribusiness, both in economic development, with generation of jobs and income (Siqueira, Carneiro, Almeida, \& Souza, 2010), and in a social aspect, reducing rural exodus (Passetti, Eiras, Gomes, Santos, \& Prado, 2016).

Dairy herd in Acre State is characterized by low productivity about 23,000 farms. Of these, $83 \%$ is composed of smallholder livestock producers, with herds of up to 100 heads. In 2019, state production totaled 42.47 million liters of milk (Instituto Brasileiro de Geografia e Estatística [IBGE], 2019; Reis et al., 2019).
Dairy product demand has increased considerably around the world and, consequently, consumers have become increasingly demanding in terms of quality (Empresa Brasileira de Pesquisa Agropecuária [EMBRAPA], 2019).

According to Soares and Gaglietti (2015), farms with worse performance regarding quality undergo typical management problems: lack of planning, clarity regarding business health, disengaged employees, and financial difficulties. Good management allows identifying possible administrative obstacles and failures, providing support for decision-making (Fassio, Reis, \& Geraldo, 2006). 
Management tools are essentially technical for use in the company to solve administrative problems usually related to the poor performance of processes, being predominantly used to identify, observe, and analyze problems, and used as preventive, corrective, and team commitment measures for their success (Meireles, 2001).

However, few studies are related to livestock, especially regarding milk quality. In the State of Acre, Reis et al. (2019) analyzed 100 dairy farming properties using management tools and observed good results in minimizing failures and increasing profitability.

Given the importance of the subject and the scarcity of studies, this research was carried out to analyze the applicability of management tools such as SWOT matrix (Passetti et al., 2016), brainstorming (Werkema, 1995), GUT matrix (Meireles, 2001), Ishikawa diagram (Lins, 1993), PDCA cycle (Vieira, 2007), and 5W2H (Werkema, 1995) to find and solve, or at least minimize, problems related to milk quality on rural properties under family labor in the municipality of Senador Guiomard, State of Acre, Brazil.

\section{Material and Methods}

This study was approved by the Ethics Committee on Animal Use of the Federal University of Acre (CEUA-UFAC) and registered under the No. 23107.020486/ 2018-47 and protocol number 50/2018.

The study was carried out in 18 rural milk-producing properties in a family economy regime in the municipality of Senador Guiomard, State of Acre, Brazil, from January to December 2019. These producers were selected using non-probabilistic sampling by judgment through the registration at the State Secretariat of Production and Agribusiness of Acre (SEPA).

The evaluated properties were under under extensive tropical grazing conditions, with occasional concentrate supply during forage shortage periods. Predominant breeds were Girolando and mongrel animals, which have average yields of 24,982 liters milk per year, 68 liters per day, and 4.0 liters per cow/ day.

The farms are characterized by familybased management. On some farms, cows are milked by hand with calf at the foot. Only one farmer (6\%) milks twice a day. In more than half of properties (56\%) milking is mechanical. In 13 properties (72\%), milk is not stored and is transported to dairies and/or consumers on the same day. Only two properties have expansion tanks (11\%), three (17\%) store milk in domestic freezers, and five sell it informally.

The evaluated properties have adopted a traditional production system, with little or no technology and good milking practices, which leaves them out of the standards established by the IN 77.

A diagnosis of the properties was carried out on the first visits using a semistructured form containing 255 questions divided into the register of the producer (52 questions) and the property (12 questions), characterization of the herd and milk production, with a higher emphasis on quality and milking management (191 questions).

Milk analyses (SCC and TBC) were carried out monthly (July to December 2019) to attest to the effectiveness of the use of management tools in improving milk quality, as these results are used worldwide as indicators of milk quality (Pantoja, Reinemann, \& Ruegg, 2011). 
Milk samples were collected individually in the properties directly from the expansion tank $(n=2)$ and cans $(n=16)$, following the collection rules according to article 40 of IN 77/2018 and Official Letter No. 113/2009 DIPOA/MAPA, in sterile $40-\mathrm{mL}$ bottles, one of them containing a Bronopol ${ }^{\circledR}$ tablet (Silveira, Fonseca, Lago, \& Veiga, 2005), and the other with Azidiol ${ }^{\circledR}$ (Sampaio et al., 2015), packed in isothermal boxes ( 4 to $8{ }^{\circ} \mathrm{C}$ ), and transported by air to the Laboratory of Milk Quality of Goiânia (LQL-GO).

The sample population was divided into two groups, according to the producers' interest in carrying out measures of good milking practices:

a) Treatment group (TG): nine properties, in which producers carried out one or more measures for the management of good milking practices.

b) Control group (CG): nine properties, in which producers have not carried out any measures for the management of good milking practices, providing only the data for the research.

The following good milking practices were suggested: 1) disregard the first jets of milk; 2) black-bottomed mug test; 3) predipping: immersion of teats with chlorinated water at 750 ppm; 4) drying with paper towels; 5) California mastitis test (CMT); 6) postdipping: disinfectant solution; 7) vigorous washing of the milking utensils with suitable products; 8) inversion of buckets/cans; 9) sanitization of pre-milking utensils; 10) washing of milking machine and milk claws as recommended by the manufacturer; 11) milking machine hygiene; 12) cleaning of facilities; 13) training and qualifications (Vallin et al., 2009; Matsubara et al., 2011; Bozo et al., 2013).

The SWOT matrix tool was used (Passetti et al., 2016). To obtain the strengths and weaknesses, opportunities and threats found in properties. The weaknesses were listed as weak points and scored using the GUT matrix, in which each researcher assessed individually and scored from zero to five the items considered more serious, more urgent, and more likely to worsen, according to Lopes, Reis and Ferrazza (2016a) and Lopes et al. (2018). Subsequently, the Brainstorming tool (Werkema, 1995) allowed indicating the management tools Ishikawa diagram, $5 \mathrm{~W} 2 \mathrm{H}$, and PDCA (Longaray, Laurino, Tondolo, \& Munhoz, 2017) to correct or, at least, minimize the diagnosed problems, following the methodology proposed by Lopes et al. (2016b).

This analysis enabled the generation of an action plan with the guidance of those responsible and actions to be taken, in addition to suggesting a deadline, verification of its applicability, and compliance within the described period.

The results of the six months of milk analysis were registered in Excel $^{\circledR}$ spreadsheets, with the geometric means, as established by Souza et al. (2017), defined as the $n$-th root (where $\mathrm{n}$ is the number of terms) of the multiplication of terms, according to the equation:

$$
\left(\prod_{i=1}^{n} a_{i}\right)^{1 / n}=\sqrt[n]{a_{1} a_{2} \cdot}
$$

Subsequently, the data were submitted to statistical analysis by the Wilcoxon-MannWhitney statistical test (wilcox.test) using the 
software R 3.6.1 to evaluate the significance of the differences in the results of SCC and TBC observed in the samples before, during, and after applying the management tools, and the statistical difference between groups, considering a $95 \%$ confidence $(\alpha=0.05)$.

\section{Results and Discussions}

Nineteen weaknesses were found in the properties, being listed in the GUT matrix in decreasing order by the average of the assigned score (Table 1). According to Reis et al. (2019), higher scores indicate the weaknesses that should be prioritized in an attempt to equate or minimize them.

\section{Table 1}

Scores assigned, through the GUT matrix, to each weakness related to milk quality found in the 18 dairy farms in a family economy regime located in the municipality of Senador Guiomard, Acre, Western Amazon, 2019

\begin{tabular}{|c|c|c|c|c|c|c|c|c|c|}
\hline \multirow[b]{2}{*}{ Weakness } & \multicolumn{9}{|c|}{ Score assigned by the researchers* } \\
\hline & 1 & 2 & 3 & 4 & 5 & 6 & 7 & Mean** & SD \\
\hline Non-disposal of milk unfit for consumption & 125 & 125 & 125 & 125 & 125 & 125 & 125 & 125.00 & 0.00 \\
\hline Incorrect hygiene of equipment and utensils & 125 & 125 & 125 & 125 & 125 & 125 & 125 & 125.00 & 0.00 \\
\hline $\begin{array}{l}\text { Lack of knowledge about good milking } \\
\text { practices }\end{array}$ & 125 & 125 & 125 & 125 & 125 & 125 & 125 & 125.00 & 0.00 \\
\hline High incidence of mastitis & 125 & 125 & 125 & 125 & 125 & 125 & 125 & 125.00 & 0.00 \\
\hline $\begin{array}{l}\text { Lack of control of brucellosis and } \\
\text { tuberculosis }\end{array}$ & 125 & 125 & 100 & 125 & 125 & 125 & 125 & 121.43 & 8.75 \\
\hline Incorrect handling in drying animals & 125 & 100 & 125 & 125 & 125 & 125 & 125 & 121.43 & 8.75 \\
\hline Use of collective cloth for teats hygiene & 125 & 125 & 125 & 125 & 125 & 64 & 125 & 116.29 & 21.35 \\
\hline Positive Alizarol ( ${ }^{\circ} \mathrm{GL}$ ) analysis & 125 & 100 & 125 & 125 & 125 & 64 & 125 & 112.71 & 21.68 \\
\hline $\begin{array}{l}\text { Incorrect handling of the milking machine/ } \\
\text { claws }\end{array}$ & 80 & 100 & 75 & 125 & 80 & 80 & 60 & 85.71 & 19.35 \\
\hline Improper milk storage & 64 & 125 & 75 & 125 & 45 & 125 & 24 & 83.29 & 38.99 \\
\hline $\begin{array}{l}\text { Incorrect teat hygiene before and after } \\
\text { milking }\end{array}$ & 125 & 24 & 80 & 32 & 125 & 27 & 125 & 76.86 & 45.13 \\
\hline Inadequate cleaning products for milking & 60 & 100 & 64 & 80 & 64 & 80 & 64 & 73.14 & 13.30 \\
\hline Lack of goals for milk quality & 60 & 80 & 64 & 80 & 64 & 27 & 64 & 62.71 & 16.41 \\
\hline Failure to perform water treatment & 100 & 80 & 8 & 16 & 100 & 125 & 3 & 61.71 & 47.35 \\
\hline Incorrect facilities & 45 & 30 & 45 & 45 & 30 & 60 & 50 & 43.57 & 9.90 \\
\hline Facilities of difficult cleaning & 45 & 30 & 45 & 45 & 30 & 1 & 50 & 35.14 & 15.72 \\
\hline Milking with calf at foot & 16 & 6 & 3 & 9 & 6 & 8 & 6 & 7.71 & 3.81 \\
\hline
\end{tabular}

*Multiplication of scores from zero to five for the requirements severity (S), urgency (U), and trend (T); **Simple arithmetic mean; SD: standard deviation. 
This article discusses the points that received the highest score in the GUT matrix, namely: the non-disposal of milk unfit for consumption; incorrect hygiene of facilities, equipment, and utensils; lack of knowledge about good milking practices; and high incidence of mastitis.

\section{First weakness: non-disposal of milk unfit for consumption}

The disposal of milk unfit for consumption was not carried out in 12 properties (67\%). According to RIISPOA, milk unfit for human consumption is out of physical and chemical standards, such as high acidity, foreign substances, drug and pesticide residues, mastitic milk, and presence of colostrum (Ministério da Agricultura, Pecuária e Abastecimento [MAPA], 2017).
All the analyzed properties did not respect the grace period for antibiotics and pesticides. Nascimento, Junqueira, Carneiro, Ramos, Abdallah and Fracalossi (2015) found a similar result in Alegre, ES, where $64 \%$ of the analyzed properties did not respect the grace period. Estevão, Garino, Santos, Silva and Matos (2015) pointed out that the occurrence of antibiotic and pesticide residues in milk constitutes a risk to public health and losses to the industry.

Management tool proposed to solve the first weakness: $5 \mathrm{~W} 2 \mathrm{H}$

The $5 \mathrm{~W} 2 \mathrm{H}$ tool is a reference to support decisions, allowing the monitoring or development of a given project (Werkema, 1995). Veiga, Polacinski, Silva, Tauchen and Pires (2013) described this tool as an action plan for any pre-established activity, answering seven questions (Table 2)

\section{Table 2}

Application of the $5 \mathrm{~W} 2 \mathrm{H}$ management tool to solve the weakness: Non-disposal of milk unfit for consumption

\begin{tabular}{|c|c|c|}
\hline & QUESTION & ACTION \\
\hline \multirow{7}{*}{$5 \mathrm{~W} 2 \mathrm{H}$} & What? & Disposal of milk unfit for consumption \\
\hline & Why? & Fitting into legislation and impact on public health \\
\hline & Where? & Milking parlor \\
\hline & Who? & Producer \\
\hline & When? & Whenever there is it \\
\hline & How? & $\begin{array}{l}\text { Do not send to the dairy company, nor for family consumption, but can be } \\
\text { supplied to calves }\end{array}$ \\
\hline & How much? & Accounting by liters; it influences the activity profitability, reducing revenue \\
\hline
\end{tabular}


Second weakness: incorrect hygiene of milking equipment and utensils

All 18 properties (100\%) cleaned incorrectly the equipment and utensils using soda soap, washing powder, or neutral detergent, without any type of water treatment. According to Reinemann, Wolters, Billon, Lind and Rasmussen (2003), the effectiveness of cleaning milking equipment and tools is related to factors such as time, temperature, volume, concentration of detergent and turbulence of cleaning solutions, and adequate drainage (Oliveira et al., 2015).

Rangel et al. (2014) assessed dairy properties in the Agreste region of the State of Rio Grande do Norte and observed that properties that performed the correct cleaning of the milking equipment had low TBC.

Management tool proposed to solve the second weakness: PDCA cycle

The PDCA cycle was proposed due to the continuous nature of the problem since this tool is a managerial decision-making method that guarantees the achievement of the goals necessary for the survival of an organization (Longaray et al., 2017). The PDCA cycle was presented as follows:

Plan - establishing a routine for cleaning milking equipment and utensils after milking.

Do - cleaning with alkaline-chlorinated detergent and water at the initial temperature of $70{ }^{\circ} \mathrm{C}$ and the final temperature of $45^{\circ} \mathrm{C}$, for 10 minutes. Acid detergent with an inlet temperature from 35 to $45^{\circ} \mathrm{C}$ for 10 minutes. Buckets, cans, and mugs must be washed with alkaline detergent and warm water, using appropriate brushes or sponges, which must be rinsed immediately after milking.

Check - through visual, tactile, and microbiological analysis.

Action - correct possible failures and validate assertive actions and make them routine in the property.

Third weakness: lack of knowledge about good milking practices

According to Dereti, Gonçalves, \& Zanela (2019), the lack of adoption of good milking practices by the milking personnel can be justified by the absence or deficiency of knowledge regarding the importance of each procedure. Battaglini, Fagnan, Dungaa and Beloti (2013) detected a rapid and significant improvement in milk quality after training producers on the importance of milk quality and procedures to achieve it.

Management tool proposed to solve the third weakness: $5 \mathrm{~W} 2 \mathrm{H}$

A three-day training course for transferring information was developed and the producers involved in the research were invited to attend it (Table 3).

\section{Fourth weakness: high incidence of mastitis}

The high incidence of mastitis found in eight properties (44\%) was of a clinical nature, diagnosed through the black background mug test, since only one producer (6\%) carried out the control of subclinical mastitis using the indirect method California mastitis test (CMT). 
Table 3

$5 \mathrm{~W} 2 \mathrm{H}$ method used to solve the weakness lack of knowledge about good milking practices

\begin{tabular}{|c|c|c|}
\hline & TOOL & ACTION \\
\hline \multirow{7}{*}{$5 \mathrm{~W} 2 \mathrm{H}$} & What? & Training course \\
\hline & Why? & Dissemination of knowledge about the quality of milk produced in the properties \\
\hline & Where? & Colônia Três de Junho \\
\hline & Who? & Producers \\
\hline & When? & June 19, 20, and 21, 2019 \\
\hline & How? & Through lectures and demonstrative practices \\
\hline & How much? & Course offered free of charge by SENACIAC \\
\hline
\end{tabular}

Failure in the diagnosis of clinical and subclinical mastitis is an important factor for the uncontrolled disease in the herd (Santos \& Fonseca, 2019). Lopes etal. (2012) emphasized that mastitis is considered the most relevant disease in dairy cattle, causing direct and indirect economic losses, which may represent 15 to $24 \%$ of gross income (Vissio, Agüero, Raspanti, Odiernob, \& Larriestra, 2015).

\section{Management tool proposed to solve the fourth weakness: ishikawa diagram}

Considering the multifocal factor of the disease, the proposed management tool was the Ishikawa diagram (Figure 1), which allows the cause and effects to be demonstrated through a composition in which the main axis indicates the problem, and the sub-axes indicate the causes, resembling a fishbone (Lins, 1993).

The tools were implemented to join the Good Agricultural Practices (GAPs) program in milking management in the studied properties. Nine producers (50\%) showed no interest in carrying out practices to improve milk quality, thus being the control group. Soares, Duarte, Carrijo and Costa (2019) also encountered resistance on the part of producers, mainly on the cleaning and hygiene of utensils, as obtained in this study.

All five farmers (28\%) selling milk informally were interested in introducing good milking practice measures, concerning about final consumers given their close contact with them. A different result was found by Dutra, Castagnara, Hoch, Tadielo and Dinarte (2020) in Uruguaiana (RS), where farmers selling informally showed no interest in receiving training to improve hygiene practices in milking.

Few practices used to be performed at the beginning of this study, often due to lack of knowledge. Picoli et al. (2015) reported a negative correlation between family farming and producer education, milk quality, management, and productivity.

No practices were added in the management of CG properties during the research period. The practices implemented by all TG producers (100\%) were the filtering of milk to eliminate physical contaminants, inversion of buckets/cans to eliminate residual water, and hygiene of facilities, as they are simple and easy. 


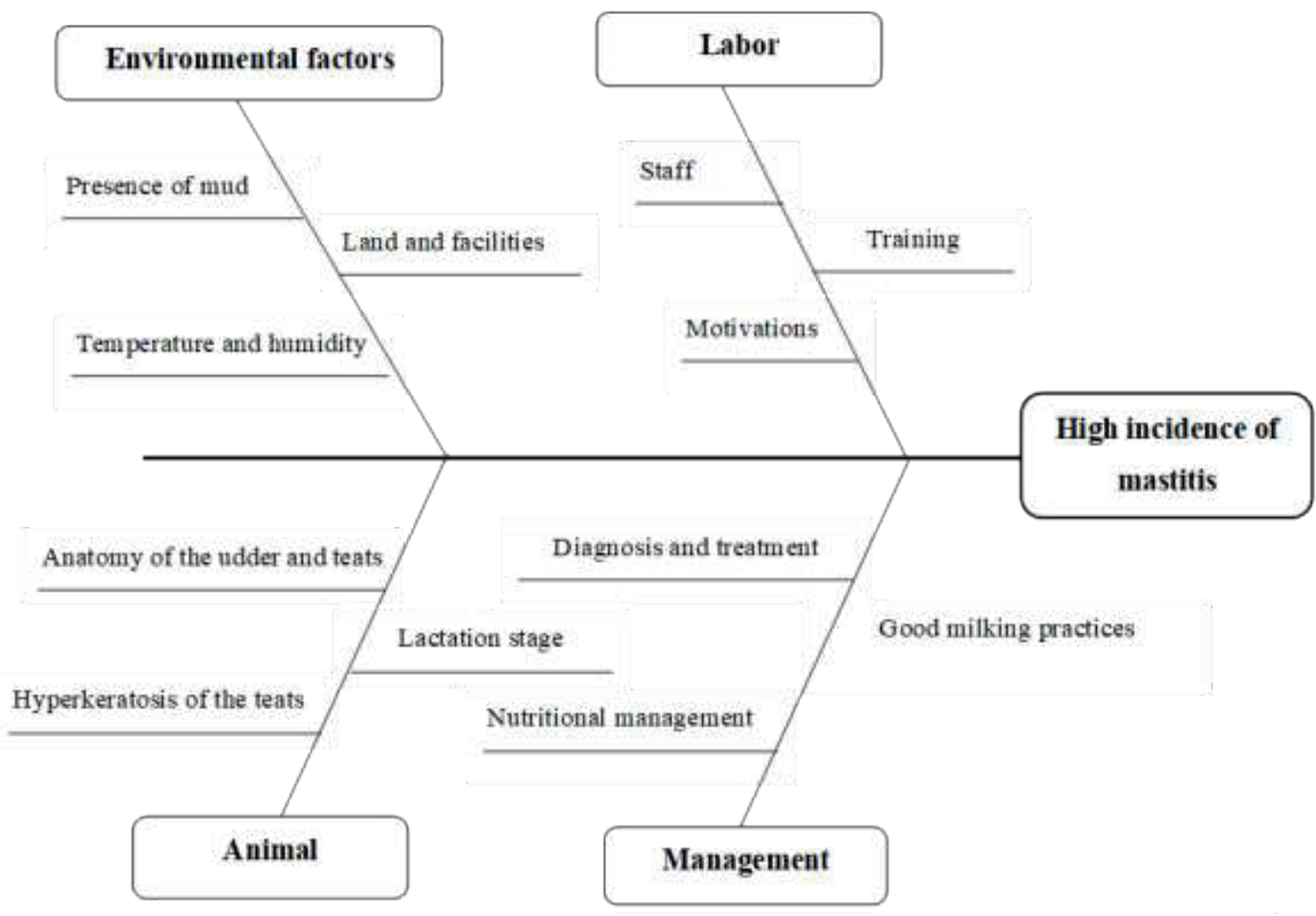

Figure 1. Ishikawa diagram as a proposal for the resolution of the weakness high incidence of mastitis.

Constantino et al. (2019) demonstrated that the main critical points of contamination by microorganisms are utensils (buckets/ cans) and teats of animals, with residual water being the main source of contamination. Matsubara et al. (2011) found significant results when applying good practices to reduce microorganisms from milk claws and teats $(99.6 \%)$, cans $(80.0 \%)$, buckets $(99.9 \%)$, and elimination of residual water from cans (100\%).

The selective dry cow therapy was also accepted by all TG producers (100\%), as they understood the importance of mastitis control (Langoni et al., 2017).

However, only two properties implemented post-dipping, which showed a high incidence of subclinical mastitis in the herd, over $60 \%$ of lactating cows. A similar result was found by Nascimento et al. (2015) on family farms in the city of Alegre - ES, where only $6 \%$ of the evaluated farms performed post-dipping.

Four geometric means were obtained from the result of the six milk analyses (Table 4), as established in the Technical Regulation of chilled raw milk (Normative Instruction No. 76/2018). TBC showed a reduction $(p<0.05)$ in milk from the TG properties and an increase was observed in CG. SCC showed no statistical difference ( $p>0.05)$ between groups. The variation in the indicators SCC and TBC between the studied properties considering the legislation standards (IN 76 and 77) ranged 
from low to very high $(\mathrm{SCC}=2361 \pm 65 \times 1000$ $\mathrm{SC} / \mathrm{mL} ; \mathrm{CBT}=1314 \pm 15 \times 1000 \mathrm{CFU} / \mathrm{mL}$ ), probably due to factors such as management, herd, and breeds, which differed between the studied properties.

\section{Table 4}

Values obtained for the total bacterial count $(\times 1000 \mathrm{CFU} / \mathrm{mL})$ and somatic cell count $(\times 1000 \mathrm{SC} / \mathrm{mL})$ of dairy farms in the municipality of Senador Guiomard, AC, Brazil, before and after the implementation of management tools

\begin{tabular}{|c|c|c|c|c|c|c|}
\hline & \multicolumn{6}{|c|}{ TREATMENT } \\
\hline & \multicolumn{3}{|c|}{$\mathrm{SCC}^{\mathrm{NS}}$} & \multicolumn{3}{|c|}{$\mathrm{TBC}^{*}$} \\
\hline & Before & After & Difference (\%) & Before (b) & After (a) & Difference (\%) \\
\hline P1 & 69 & 107 & 34.82 & 369 & 168 & -54 \\
\hline P2 & 1643 & 816 & -50.32 & 799 & 365 & -54 \\
\hline P3 & 65 & 74 & 12.14 & 140 & 50 & -64 \\
\hline P4 & 144 & 130 & -10.00 & 58 & 10 & -81 \\
\hline P5 & 96 & 123 & 22.01 & 44 & 33 & -25 \\
\hline P6 & 406 & 234 & -42.29 & 25 & 21 & -14 \\
\hline P7 & 498 & 232 & -53.33 & 1163 & 247 & -79 \\
\hline P8 & 432 & 566 & 23.71 & 1270 & 463 & -63 \\
\hline P9 & 109 & 90 & -17.31 & 172 & 131 & -23 \\
\hline \multirow[t]{4}{*}{ Mean } & 385 & 264 & -31.42 & 449 & 165 & -63.02 \\
\hline & \multicolumn{6}{|c|}{ CONTROL } \\
\hline & \multicolumn{3}{|c|}{ SCC $^{\mathrm{NS}}$} & \multicolumn{3}{|c|}{$\mathrm{TBC}^{\mathrm{NS}}$} \\
\hline & Before & After & Difference (\%) & Before (b) & After (a) & Difference (\%) \\
\hline $\mathrm{P} 1$ & 186 & 130 & -30 & 15 & 18 & 20 \\
\hline P2 & 190 & 277 & 45 & 134 & 506 & 275 \\
\hline P3 & 202 & 161 & -20 & 1286 & 574 & -55 \\
\hline P4 & 2361 & 1013 & -56 & 815 & 1119 & 37 \\
\hline P5 & 195 & 260 & -33 & 1314 & 1571 & 19 \\
\hline P6 & 523 & 301 & -42 & 1039 & 2241 & 115 \\
\hline P7 & 154 & 124 & -19 & 68 & 93 & 35 \\
\hline P8 & 254 & 184 & -27 & 221 & 241 & 8 \\
\hline P9 & 294 & 192 & -34 & 223 & 478 & 114 \\
\hline Mean & 484 & 294 & -39.35 & 568 & 760 & +33.70 \\
\hline
\end{tabular}

P: analyzed properties. *Significant divergence between groups. NSNot significant between groups $(P \leq 0.05)$.

The average SCC and TBC of the nine TG properties before the introduction of the tools was $385 \times 1000 \mathrm{SC} / \mathrm{mL}$ and $449 \times 1000$
$\mathrm{CFU} / \mathrm{mL}$, respectively. On the other hand, $264 \times 1000 \mathrm{SC} / \mathrm{mL}$ and $166 \times 1000 \mathrm{CFU} / \mathrm{mL}$ were obtained after the implementation of the 
tools. Average reductions of 31.42 and $63 \%$ were observed for SCC and TBC, respectively.

The initial average values for CG were $485 \times 1000 \mathrm{SC} / \mathrm{mL}$ and $569 \times 1000 \mathrm{CFU} / \mathrm{mL}$, reaching $294 \times 1000 \mathrm{SC} / \mathrm{mL}$ and $761 \times 1000$ CFU/mL after the six months of collection, with an average reduction of $39.32 \%$ and an increase of 33\% for SCC and TBC, respectively.

Vallin et al. (2009) observed an average reduction of $87.9 \%$ for TBC in manual milking and $86.9 \%$ in mechanized milking. Bozo et al. (2013) compared the average of dairy farms in the city of Pitangueiras, Paraná, and also found an average reduction of $93.4 \%$ for TBC.

The lower values found in this research $(63 \%)$ were probably due to the nonimplementation of all GAPs in the studied properties. The adequacy of cleaning the utensils and milking equipment using suitable products presented the highest resistance on the part of producers (83\%). This fact is related to the non-existence of these products in the market in the State of Acre and the complexity of execution reported by producers. Similarly, Soares et al. (2019) reported a difficult standardization of disinfectant dilutions and failure to execute the correct action time.

The average values of SCC decreased (31.4\%), but no statistically significant difference $(p<0.05)$ was observed when the results were compared before and after the use of the management tools (Figure 2). Similar results were found by Soares et al. (2019), which were different from those observed by Bozo et al. (2013), who obtained reduction averages of $74.3 \%$ for CCS.

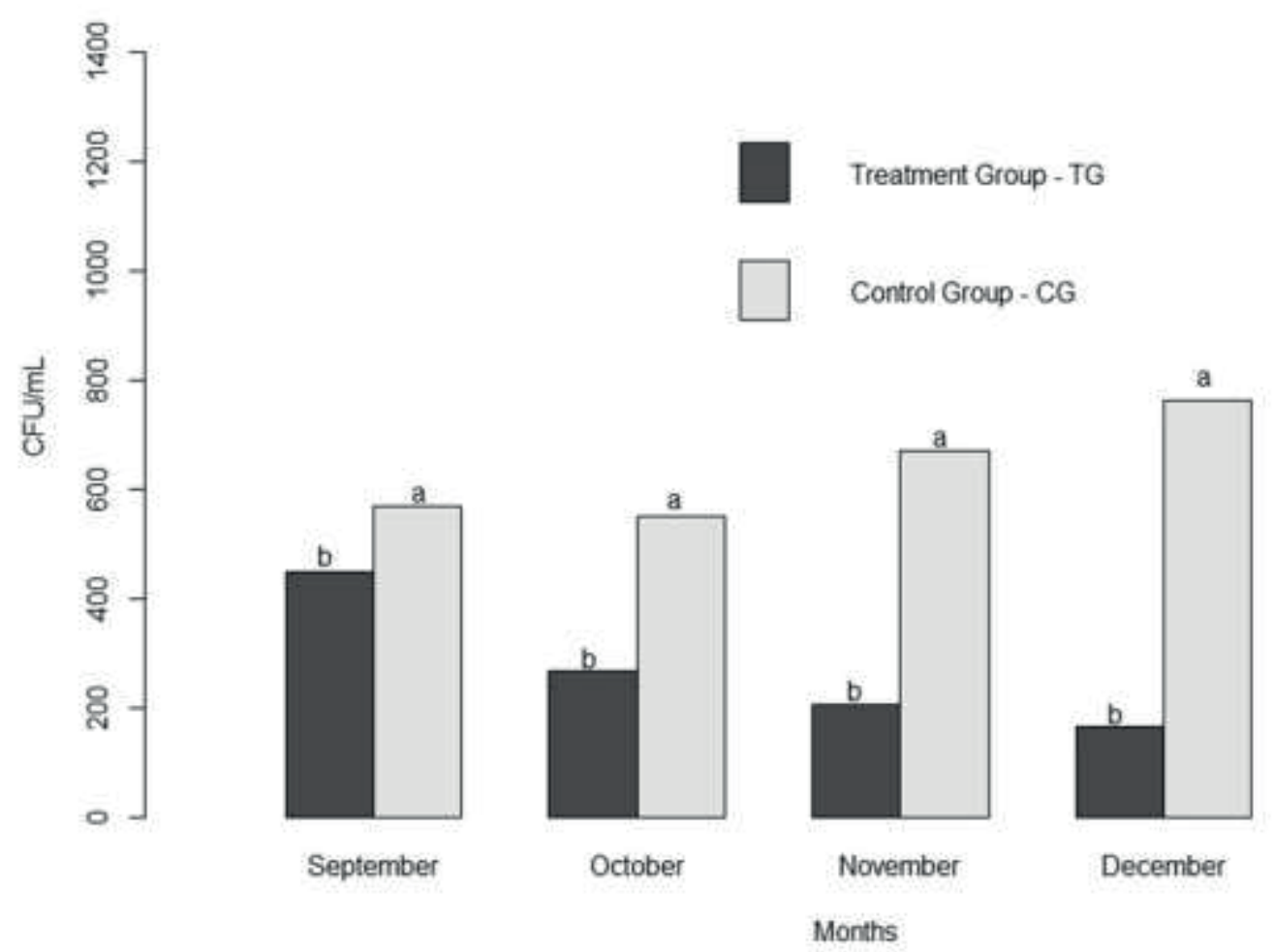

Figure 2. Behavior of geometric means for total bacterial count between groups evaluated from July to December 2019. 
The non-significant improvement for SCC is related to the short term of the study, as the response to the implementation of good practices for SCC is not as immediate and significant as for TBC. Pre-and postmilking cleaning and hygiene are capable of reducing TBC by $98 \%$ on the first day of implementing good practices (Silva et al., 2011). Soares et al. (2019) observed that the results of implementing good practices for SCC are obtained in the next lactation after the animals have dried.

The significant increase in TBC in CG (33.7\%) is believed to be related to the local rainy season (September to December), with rainfall of approximately $1,150 \mathrm{~mm}$ during this period according to the Brazilian National Institute of Meteorology (Inmet). Picinin et al. (2019) observed an increase in the SCC and TBC parameters during a period with rainfalls and high temperatures (October to January), favoring an increase in environmental contamination, accumulation of mud in the facilities, and higher occurrence of dirty teats at milking time. These factors, associated with failures in the milking routine, may cause high initial contamination.

Regarding the current legislation, TG properties presented geometric means of SCC and TBC within the standards of IN $76 / 2018$, while the means of CG were out of the standard relative to TBC. According to IN No. $77 / 2018$, properties with results of geometric mean out of the CPP standards must have the milk collection interrupted and will only return to the collection with results of a new sample analyzed by the Brazilian Milk Quality Network (RBQL) within the regulatory standard (Instrução Normativa n 76 e 77 2018). Thus, it is an important economic impact.
Thus, the State of Acre lacks much information related to the quality of the produced milk. The most recent study was carried out in 2009 by Embrapa Acre in the municipalities of Acrelândia, Porto Acre, and Rio Branco. The authors reported that the microbiological quality of the fresh milk collected on the platform was out of the standards required by legislation. The values were well above those of the present study, with an average of 2,052.52 x $1000 \mathrm{CFU} / \mathrm{mL}$ (Carneiro, Cavalcante, Braga, \& Santos, 2015).

These producers had no direct financial return, as there are no bonuses or penalties for milk quality in the State of Acre. Bozo et al. (2013) evaluated the adoption of good practices in a quality payment program, which generated an increase in the monthly income of producers, with bonuses from $\mathrm{R} \$ 120.00$ to $R \$ 828.00$, according to the production of each property.

\section{Conclusion}

The management tools applied to milk quality can generate significant results $(p<0.05)$, indicated to identify weaknesses in rural properties, facilitating quick decisionmaking aiming at their correction, being characterized as a guiding document for the manager to carry out an action plan and goals to be met in the short and long term.

Several weaknesses were found related to the quality of milk from these properties and the resistance of some producers to implement good milking practices. It suggests a close relationship between producers and industry through quality improvement programs, incentives and technical assistance 
activities, and quality bonuses. Moreover, the culture of producers needs to be changed, as they have difficulties in absorbing information and applying low-cost simple management techniques.

A significant improvement $(p<0.05)$ was obtained in the quality of the produced milk regarding $T B C$ in $T G$, which did not occur in CG. On the contrary, no statistical difference ( $p>0.05$ ) was observed between groups for SCC, and both have their indices according to the IN 77 legislation, thus contributing to the sustainability of the production sector.

\section{References}

Battaglini, A. P. P., Fagnani, R., Dunga, K. S., \& Beloti, V. (2013). Dissemination of good production practices and characterization of dairy production. Archivos de Zootecnia, 62(237), 151-154. doi: 10.43 21/S000405922013000100017

Bozo, G. A., Alegro, L. C. A., Silva, L. C., Santana, E. H. W., Okano, W., \& Silva, L. C. C. (2013). Adequação da contagem de células somáticas e da contagem bacteriana total em leite cru refrigerado aos parâmetros da legislação. Arquivo Brasileiro de Medicina Veterinária eZootecnia, 65(2), 589-594. doi: 10.1590/S0102-09352013000200040

Carneiro, J. M. Jr., Cavalcante, F., Braga, A., \& Santos, C. F. dos. (2015). Qualidade do leite cru em sistema de ordenha tradicional no Estado do Acre. (Boletim de Pesquisa e Desenvolvimento, 53). Rio Branco-Acre: EMBRAPA Acre. Recuperado de https:// www.infoteca.cnptia.embrapa.br/infoteca/ bitstream/doc/1041211/1/25975.pdf
Constantino, N. A. S., Dias, J. A., Oliveira, A. M. de, Cordeiro, S. C. M., Beloti, V., \& Faria, G. V. (2019). Impacto da adoção de boas práticas na contagem de bactérias mesófilas em rebanhos em condições de produção prevalentes em Rondônia. Anais do Congresso Internacional de Pecuária Leiteira da Amazônia Ocidental, Rio Branco, AC, Brasil. Recuperado de https://www.alice.cnptia. embrapa.br/bitstream/doc/1117632/1/ AnaisCongresso19122019p66.pdf

Dereti, R. M., Gonçalves, E. B., \& Zanela, M. B. (2019). Boas práticas agropecuárias na produção leiteira: diagnóstico e ajuste de não conformidades. Arquivo Brasileiro de Medicina Veterinária e Zootecnia, 71(6), 2075-2084. doi: 10.1590/1678-4162-10 401

Dutra, C., Castagnara, D. D., Hoch, G. C., Tadielo, L. E., \& Dinarte, G. V. (2020). Os porquês do comércio informal de leite em Uruguaiana-RS. A visão do produtor. Anais do Salão Internacional de Ensino, Pesquisa e Extensão, 7. Recuperado de https://periodicos.unipampa.edu.br/index. php/SIEPE/article/view/81319

Empresa Brasileira de Pesquisa Agropecuária (2019). Anuário do leite 2019. Minas Gerais: Editora Gráfica Bernardi. Recuperado de https://ainfo.cnptia.embrapa.br/digital/ bitstream/item/198698/1/AnuarioLEITE-2019.pdf

Estevão, A. Neto, Garino, F. Jr., Santos, J. C. A., Silva, L. C. da, \& Matos, R. A. T. (2015). Avaliação de resíduo de antibiótico em amostras de leite de vacas após a terapia de vacas secas. Arquivos do Instituto Biológico, 82, 1-4. doi: 10.1590/1808-165 7000322013 
Fassio, L. H., Reis, R. P., \& Geraldo, L. G. (2006). Desempenho técnico e econômico da atividade leiteira em Minas Gerais. Ciência e Agrotecnologia, 30(6), 1154-116. doi: 10.1590/S1413-70542006000600018

Instituto Brasileiro de Geografia e Estatística (2019). Produção pecuária municipal de 2019. Recuperado de https://cidades. ibge.gov.br/brasil/pesquisa/18/16459

Instrução Normativa $n^{\circ} 76$ e 77 de 30 de dezembro de 2018. (2018). Diário Oficial da União - Imprensa nacional, Brasília, Seção 1, 30. Recuperado de https:// www.in.gov.br/materia/-/asset_publisher/ Kujrw OTZC2Mb/content/id/52750137/ do1-2018-11-30-instrucao-normativa-n76-de-26-de-novembro-de-2018-5274 9894IN\%2076

Langoni, H., Salina, A., Oliveira, G. C., Junqueira, N. B., Menozzi, B. D., \& Joaquim, S. F. (2017). Considerations on the treatment of mastitis. Pesquisa Veterinária Brasileira, 37(11), 1261-1269. doi: 10.1590/s0100$736 \times 2017001100011$

Lins, B. F. E. (1993). Ferramentas básicas da qualidade. Ciência da Informação, 22(2), 153-161. Recuperado de http://revista. ibict.br/ciinf/article/view/502

Longaray, A. A., Laurino, F. C., Tondolo, V. A. G., \& Munhoz, P.R. (2017). Proposta de aplicação do ciclo PDCA para melhoria contínua do sistema de confinamento bovino: um estudo de caso. Sistemas \& Gestão, 12(3), 353-361. doi: 10.20985/1980-5160.2017. v12n3.1123

Lopes, M. A., Demeu, F. A., Rocha, C. M. B. M. da., Costa, G. M. da., Franco, A., Neto, \& Santos, G. dos. (2012). Avaliação do impacto econômico da mastite em rebanhos bovinos leiteiros. Arquivos do Instituto Biológico, 79(4), 477-483. doi: 10.1590/S1808-16572012000400003

Lopes, M. A., Reis, E. M. B., \& Ferrazza, R. A. (2016a). Formulário de diagnóstico da propriedade leiteira. (Boletim Técnico). Lavras, UFLA.

Lopes, M. A., Reis, E. M. B., Demeu, F. A., Mesquita, A. A., Rocha, A. G. F., \& Benedicto, G. C. (2016b). Uso de ferramentas de gestão na atividade leiteira: um estudo de caso no sul de Minas Gerais. Revista Científica de Produção Animal, 18(1), 26-44. doi: 10.5935/2176-4158/rcpa.v18n1 p26-44

Lopes, M. A., Reis, E. M. B., Demeu, F. A., Mesquita, A. A., Rocha, A. G. F., Pelegrini, D. F.,... Teixeira, F. E. P., Jr. (2018). Uso de ferramentas de gestão na atividade leiteira: um estudo multicasos em Uberlândia, MG. Agropecuária Técnica (UFPB), 39(1), 7386. doi: 10.25066/agro tec.v39i1.34302

Matsubara, M. T., Beloti, V., Tamanini, R., Fagnani, R., Silva, L. C. C. da., Monteiro, A. A., \& Barros, M. A. F. (2011). Boas práticas de ordenha para redução da contaminação microbiológica do leite no agreste Pernambucano. Semina: Ciências Agrárias, 32(1), 277-285.

Meireles, M.(2001). Ferramentasadministrativas para identificar, observar e analisar problemas: organizações com foco no cliente (vol. 2). São Paulo: Arte \& Ciência. Recuperado de https://administrante.files. wordpress.com/2010/01/ferramentasadministrativas-para-identificar-observare-analisar-problemas.pdf

Ministério da Agricultura, Pecuária e Abastecimento (2017). Regulamento da Inspeção Industrial e Sanitária de Produtos 
de Origem Animal (RIISPOA). Decreto $\mathrm{n}^{\circ}$ 9.013, de 29 de março de 2017. Alterado pelo Decreto $n^{\circ} 9.069$, de 31 de maio de 2017; regulamenta a Lei $n^{\circ} 1.283$, de 18 de dezembro de 1950, e a Lei $n^{\circ} 7.889$, de 23 de novembro de 1989, que dispõem sobre a inspeção industrial e sanitária de produtos de origem animal. Recuperado de http://www.planalto.gov.br/ccivil_03/ decreto/1950-1969/D30691.htm

Nascimento, F. C. Neta, Junqueira, M. S., Carneiro, J. C. S., Ramos, M. P. P., Abdallah, F. R., \& Fracalossi, C. P. (2015). Condições de Produção de Leite em Propriedades Familiares localizadas no nunicípio e Alegre - ES, Brasil. Revista do Instituto de Laticínios Cândido Tostes, 70(3), 117-131. doi: 10.14295/2238-6416.v70i3.347

Oliveira, A. A. de, Seixas, L., Azevedo, H. C., Teixeira, K. M., McManus, C., \& Melo, C. B. de. (2015). Evaluation of the use of good practices in dairy cattle herds. Brazilian Journal of Veterinary Medicine, 37(1), 7377. Retrieved from http://rbmv.org/index. php/BJVM/article/view/340

Pantoja, J. C. F., Reinemann, D. J., \& Ruegg, P. L. (2011). Factors associated with coliform count in unpasteurized bulk milk. Journal of Dairy Science, 94(6), 2680-2691. doi: 10.3168/jds.2010-3721

Passetti, R. A. C., Eiras, C. E., Gomes, L. C., Santos, J. F., \& Prado, I. N. (2016). Intensive dairy farming systems from Holland and Brazil: SWOT analyse comparison. Acta Scientiarum. Animal Sciences, 38(4), 439446. doi: 10.4025/actascianimsci.v38i4. 31467

Picinin, L. C. A., Bordignon-Luiz, M. T., Cerqueira, M. M. O. P., Toaldo, I. M., Souza,
F. N., Leite, M. O.,... Lana, A. M. Q. (2019). Effect of seasonal conditions and milk management practices on bulk milk quality in Minas Gerais State-Brazil. Arquivo Brasileiro de Medicina Veterinária e Zootecnia, 71(4), 1355-1363. doi: 10.15 90/1678-4162-10063

Picoli, T., Zani, J. L., Peter, C. M., Roll, V. F. B., Ribeiro, M. E. R., Vargas, G. D.,... Fischer, G. (2015). Milk production characteristics in Southern Brazil. Semina: Ciências Agrárias, 36(3, Supl. 1), 1991-1998. doi: 10. 433/1679-0359.2015v36n3Supl1p1991

Veiga, R. S., Polacinski, E., Silva, V. B., Tauchen, J., \& Pires, M. P. (2013). Implantação dos 5 Ss e proposição de um SGQ para uma indústria de erva-mate. Revista ADMpg Gestão Estratégica Organizacional, 6(1), $1-78$.

Rangel, A. H. N., Araújo, V. M. de, Bezerra, K. C., Freire, R. M. B., Guerra, M. G., Lima, D. M. de Jr., Oliveira, N. A. de. (2014). Processo de higienização nos equipamentos de ordenha em propriedades leiteiras. Acta Veterinaria Brasilica, 8(2), 107-112. doi: 10.21708/avb.2014.8.2.3421

Reinemann, D. J., Wolters, G. M. V. H., Billon, P., Lind, O., \& Rasmussen, M. D. (2003). Review of practices for cleaning and sanitation of milking machines. Bulletin of the International Dairy Federation, 381, 4-18.

Reis, E. M. B., Lopes, M. A., Demeu, F. A., Bruhn, F. R. P., Lima, A. L. R., Benedicto, G. C., \& Pelegrini, D. F. (2019). Applicability of management tools to the correction of weaknesses in family dairy farms in the Western Amazon. Semina: Ciências Agrárias, 40(1), 339-352. doi: 10.5433/ 1679-0359.2019v40 n1p339 
Sampaio, V. S. C., Souza, F. N., Saraiva, C. J. C., Santos, R. P., Leite, M. O., Resende, G. M.,... Cerqueira, M. M. O. P. (2015). Influência de diferentes tipos de microorganismos na contagem bacteriana total por citometria de fluxo do leite cru refrigerado. Arquivo Brasileiro de Medicina Veterinária e Zootecnia, 67(2), 607-612. doi: 10.1590/1678-7257

Santos, M. V. dos, \& Fonseca, L. F. L. da. (2019). Controle da mastite e qualidade do leite: desafios e soluções. São Paulo: Edição dos Autores.

Silva, L. C. C., Beloti, V., Tamanini, R., Beloti, V., Tamanini, R., D'Ovidio, L.,... Pires, E. M. F. (2011). Rastreamento de fontes da contaminação microbiológica do leite cru durante a ordenha em propriedades leiteiras do Agreste Pernambucano. Semina: Ciências Agrárias, 32(1), 267-275.

Silveira, T. M. L., Fonseca, L. M., Lago, T. B. N., \& Veiga, D. R. (2005). Comparação entre o método de referência e a análise eletrônica na determinação da contagem de células somáticas do leite bovino Arqruivo Brasileiro Medicina Veterinária Zootecnia, 57(1), 128-132. doi: 10.1590/ S0102-09352005000100017

Siqueira, K. B., Carneiro, A. V., Almeida, M. F., \& Souza, R. C. N. (2010). O mercado lácteo brasileiro no contexto mundial. (Circular Técnica, 104). Juiz de Fora: EMBRAPA Gado de Leite. Recuperado de https://www. infoteca.cnptia.embrapa.br/bitstream/ doc/886169/1/CT104Kennya.pdf

Soares, E. S. M., Duarte, M. T., Carrijo, K. F., \& Costa, M. R. (2019). Application of good milking practices: economic impacts and bovine raw milk quality. Multitemas, 24(56), 41-57. doi: 10.20435/multi.v24i56.1967
Soares, V., \& Gaglietti, M. J. (2015). Rastreabilidade da cadeia leiteira como requisito de qualidade. Revista Tecnológica, 3(2), 259-267. Recuperado de https://uceff.edu.br/revista/index.php/ revista/article/view/94

Souza, G. N. de, Lange, C. C., Ribeiro, J. B., Mendonça, J. F. M. de, Silva, M. R., Brito, M. A. V. P. E.,... Mendonca, L. C. (2017). Cálculo da média geométrica da contagem de células somáticas e contagem total de bactérias utilizando planilha eletrônica do Excel para comparação com os requisitos estabelecidos pela legislação federal. (Circular Técnica EMBRAPA Gado de Leite).

Vallin, V. M., Beloti, V., Battaglini, A. P. P., Tamanini, R., Fagnani, R., Angela, H. L., da., Silva, L. C.C. da. (2009). Melhoria da qualidade do leite a partir da implantação de boas práticas de higiene na ordenha em 19 municípios da região central do Paraná. Semina: Ciências Agrárias, 30(1), 181-188. doi: 10.54 33/1679-0359.2009v30n1p181

Vieira, G., Fo. (2007). Gestão da qualidade total: uma abordagem prática (2a ed.). Campinas: Editora Alínea.

Vissio, C., Agüero, D. A., Raspanti, C. G., Odiernob, L. M., \& Larriestra, A. J. (2015). Pérdidas productivas y económicas diarias ocasionadas por la mastitis $y$ erogaciones derivadas de su control en establecimientos lecheros de Córdoba, Argentina. Archivos de Medicina Veterinária, 47(1), 7-14. doi: 10.4067/S03 01-732X2015000100003

Werkema, M. C. C. (1995). As ferramentas da qualidade no gerenciamento de processos (4a ed.). Belo Horizonte: Editora de Desenvolvimento Gerencia. 